\title{
RELIGIOUS EDUCATION AND THE CHALLENGE OF PLURALISM IN INDONESIA
}

\author{
M. Agus Nuryatno \\ UIN Sunan Kalijaga Yogyakarta Jl. Marsda Adisucipto 55281 \\ E-mail: agusnuryatno@yahoo.com
}

\begin{abstract}
This paper discusses the issue of religious education in relation to the challenge of religious pluralism in Indonesia. The focus of this paper is: On finding out the kind of religious education that is compatible with the challenge of religious pluralism? By employing concept of religious pluralism and theory of religious education, this paper argues that to face the challenge of religious pluralism it is necessary to change the model of religious education from in, to at and beyond the wall. Religious education in the wall contributes to shape an exclusive model of religiosity; while religious education at and beyond the wall contributes to shape an inclusive and pluralist model of religiosity. The last two models are compatible to be applied in Indonesia in order to face the challenge of pluralism, because both of them help students to accept, respect, and value religious differences. Religious education should show that the common enemy of religion is not people of different faiths, but poverty, corruption, violence, ignorance, and the like, and they have to stand together to fight against these true enemies.
\end{abstract}

Keywords: Religious education, Pluralism, In, at and beyond the wall

\begin{abstract}
ABSTRAK
Tulisan ini bermaksud membahas pendidikan agama dalam bubungannya dengan tantangan pluralisme agama di Indonesia. Fokus dari tulisan ini adalah mencari jenis pendidikan agama yang cocok dengan tantangan pluralisme agama. Dengan menggunakan konsep pluralisme agama dan teori pendidikan agama, tulisan ini menunjukkan babwa untuke menghadapi tantangan pluralisme agama itu perlu mengubah model pendidikan agama dari 'dalam', 'di' dan 'di luar dinding'. Pendidikan agama 'di dalam dinding' memberikan kontribusi dalam membentuk model eksklusif religiusitas, sedangkan pendidikan agama 'di' dan 'di luar dinding' memberikan kontribusi dalam membentuk sebuah model pluralis dan religiusitas inklusif. Kedua model yang terakhir adalah yang cocok untuk diterapkan di Indonesia dalam rangka menghadapi tantangan pluralisme, karena keduanya membantu siswa untuk menerima, menghormati dan menghargai perbedaan agama. Pendidikan agama harus menunjuk.kan bahwa musub bersama agama bukanlah orang yang berbeda agama, tetapi kemiskinan, korupsi, kekerasan, kebodohan dan sejenisnya, dan mereka harus berdiri bersama-sama untuk melawan musub-musub sejati.
\end{abstract}

Kata Kunci: Pendidikan agama, Pluralisme, 'Dalam', 'Di' dan 'Di luar dinding' 


\section{INTRODUCTION}

Indonesia is neither secular nor Islamic state, but somewhere between the two. The Indonesian founding fathers opted to choose Pancasila as an ideological basis of this country instead of secular nationalism or Islam. Pancasila, consisting of five principles--spirituality, humanity, unity in diversity, democracy, and social justice-- reflects the compromise between those who struggle for national secularism and for an Islamic state. The compromise is also found in Article 29 of 1945 Constitution concerning religion. Section 1 and 2 of the Article states the following: (1) The state is based on Ketuhanan Yang Maha Esa; (2) The state guarantees the freedom of each citizen to embrace his/her religion and to observe the rituals according to his/her religion and belief. Although Indonesia does not proclaim itself as an Islamic or religious state, in fact Indonesian society is well known as religious society. In Indonesia, religion is part of, not a part of, societal life.

There is no wonder that the government pays a lot of attention to religious life. One of its examples is by establishing Department of Religious Affairs in January, 1946, soon after the independence of Indonesia. It was Sutan Syahrir, as a Prime Ministry in that time, who established this institution. This department still exists until today and probably none of the future Presidents would like to abolish this department, otherwise would face a big resistance from the Muslims (Mujiburrahman: 2008). Another example of how state pays a lot of attention to religious life is by introducing religious education to formal school, from elementary to higher education.

However, the government's concern to the religious education is very challenging. The diversity of religion in Indonesia affects the government decision to apply the appropriate religious program especially in formal school. In particular, it must give religious value to the students in certain religion but it does not interfere the students who have another faith. For example, some state schools are generally moslems students, thus, the main religious lesson is Islam. For those who have different faith, they may have their own religious lesson given by their own preach outside the school. This condition may seem to be tolerable but it may be less effective for religious education in Indonesia. The question is: How to construct a model of religious educations that is compatible with the diverse society like Indonesia?

Given the above description, this paper attempts to argue that religious education should be shifted from merely teaching and talking about its own religion to a model of religious education that connects one religion to another, arguing that such kind of shifting would make pupil aware of other religions and build tolerance amongst students of different faith. Shifting model of teaching religion from an "exclusive" to an "inclusive" one would also make religious education compatible, relevant, and in accordance with the challenge of pluralism. 


\section{ANALYSIS}

Religious education plays important role in Indonesia. It has been applied both in formal and informal education. Grimmit (1987: 67-68) proposes some meanings of religious education. He distinguishes religious education as learning religion, learning about religion, and learning from religion. First, religious education as learning religion means the transmission of religious culture, belief, and values from one generation to the next generation. The function of religious education in this perspective is to perpetuate and to hand on religious values and tradition. Second, religious education as learning about religion means studying religion in a pure objective and descriptive manner, not merely absorbing or receiving religious values. This approach can be called as an objective form of teaching religion. Last, the third distinction is learning from religion, which refers to the following: what advantages will be gained by individuals who study religion; how religion could possibly contribute to illuminate the problems of human beings; and how religion could shape character within learners. Unlike Grimmit who prefers choosing the last meaning as the definition of religious education, however, the above three definitions could be applied to religious education. By defining religious education as learning religion, learning about religion, and learning from religion, people are trying to seek value of religion particularly in dealing with the reality of multiculturalism, pluralism, and diversity of society. These definitions of religious education could also make the study of religion illuminate the problems of human living.

In addition, Habermas (1971) distinguished three modes of knowledge: technical, interpretative, and emancipatory knowledge. The next interesting point is that how possible it is to locate religious education as one of the emancipatory disciplines within the critical social sciences, one whose goal is human freedom, as proposed by Habermas (1971). When religious education was located as one of the emancipatory disciplines, then its role does not only comprising the study of religion, but also revealing the ambiguity of religion, Opening up the treasures of religion, its liberating and life affirming aspects to human beings. Religious education in this sense has power either to support or to decrease the ideal society of diversity; it depends on how it is constructed, formulated, and delivered. If religious education is to be looked in this way, then religious education must adopt a critical stance.

Another theory of religious education that this paper would like to employ is theory of models of religious education proposed by Jack Seymour. Seymour (1997) divided models of religious education into two: (a) religious education in the wall and (b) religious education at the wall.

In particular, Seymour (1997) stated that religious education in the wall is a model of religious education that concerns only one own religion, without connecting it to other religion. This is a phase of faith formation and typical of exclusive model of religious education. Moreover, Seymour (1997) also stated that the next model, at the wall, is a model of religious education that is not only 
concern with its own religion, but it has been linked to other religions and has used common terms to speak to the world or other faiths. This is a phase of faith transformation by learning and appreciating people of other faiths and conducting interreligious dialogue. Interreligious dialogue can be seen as a search for the maximum common denominator, or as a broader sense, of "common values."

Meanwhile, Christiani (2009: 173-191) completed the theory of model of religious education. She put forwards the model by adding beyond the wall. In other words, this is praxis model of religious education. Religious education beyond the wall means helping students to work together with people of other faiths for peace, justice, and harmony. This is a phase of faith praxis, namely to connect between theory and practice, faith and deed, in order to make religion more meaningful for human life and to make a better world. Different faith at exoteric level does not mean a barrier to work together fighting against the main enemy of religion, such as poverty, violence, corruption, manipulation, and the like.

\section{Religious Education: Historical View}

Basically, the dynamic of religious education in Indonesia begins from Soekarno, Soeharto, and reformation era. The religious education had been introduced to formal education since the early period of Indonesian independence. In 1946, BPKNIP decided that religious education should become part of national education system and must be included to national curricula. In the same year, the government through Ministry of Religious Affairs and Ministry of Education, Teaching, and Culture released a joint decree mentioning that religious education would be taught only from $4^{\text {th }}$ class to $6^{\text {th }}$ class of SR (Sekolah Rakyat-Elementary School). However, this joint decree was ineffective because of unstable condition of Indonesia, proven by the fact that outside Java religious education was taught since class I of elementary school. For this reason, the government constituted the Consideration Council of Islamic Teaching in 1947, led by Ki Hajar Dewantoro and Prof. Drs. Abdullah Sigit, to redesign religious education in formal education (Zuhairi, 1997: 154).

When the situation was getting better in 1950, the government established a new committee led by Prof. Mahmud Yunus from the Department of Religious Affairs and Mr. Hadi from the Department of Education and Culture. The task of the committee was to redesign religious education that could be implemented in all over Indonesia. The result of the committee was a joint decree between these ministries that stated:

1. Religious education was taught since class $4^{\text {th }}$ of elementary school.

2. In regions where their religious community were very influential (like in Sumatra, Kalimantan, and the like) religious education was taught since first class of elementary school. 
3. At secondary and high school (general or vocational) level, religious education was taught twice in a week.

4. Religious education was taught under condition that there were at least 10 pupil in the class and had permission from their parents.

5. Religious teacher's appointment, the expense of religious education, and subject matter of religious education were a responsible of Ministry of Religious Affair.

In order to complete the curricula the government established another committee led by KH. Imam Zarkasyi, a founder of Pondok Gontor Ponorogo, in 1952. Thus, only in five years (1947-1952) the government had established three committees in order to rearrange religious education in Indonesia, and this showed that the government paid a serious attention to this matter. Based on the above decree, religious education was applied differently, meaning that every region in Indonesia has different implementation of religious education. In addition, religious education was fully managed by Ministry of Religious Affairs, this means that religious education was not been integrated fully to the national education system.

In the following years, there was a political turbulence since Soekarno released a decree in July 5, 1959, and this political change contributed to the changing of religious education. In a plenary meeting of MPRS on February 1960 , in regard to religious education (chapter III article 3) it was decided that "religious education becomes a subject that is taught in public schools, from elementary school to university," under condition that the parents allow their children to take that subject. In contrast, if their parents did not allow them to take, they might leave the class. This was different from UUPP No. 4, 1950 article 20 point 1 stating that religious education was just taught in public school since elementary school until junior high school.

In the early of Soeharto's regime, there was a radical change in terms of religious education. In the previous time, religious education was just an optional matter, meaning that it could only be taken with the permission from their parents. In contrast, in the era of Soeharto, religious education was a compulsory lesson from elementary school until university. This policy might be based on two reasons: first, to prevent students from the influence of communism, a state common enemy; and secondly, to show the increasing significance of religion in national politics (Mujiburrahman: 2008). Thus, it could be said that religious education had been used by Soeharto to oppose communism and to show his stance towards religion.

Considering to the previous event above, actually the basis of regulation that makes religious education became a compulsory subject was the decision of TAP MPRS No. XXII/MPRS 1966 about Religion, Education, and Culture Point 1 stating that religious education was an obliged lesson from elementary school until state university (Mudyahardjo, 2002: 422). Therefore, since 1966, 
wherein Soeharto had already in reign, religious education became a compulsory lesson.

In October 23, 1967, Minister of Religious Affairs and Minister of Education and Culture released a joint decree that decided students of $1^{\text {st }}$ and $2^{\text {nd }}$ class of elementary school to be taught religious education two hours a week, $3^{\text {rd }}$ class 3 hours a week, and $4^{\text {th }}$ up to $6^{\text {th }}$ class four hours a week. Steenbrink (1994: 94) said that in 1970 Minister of Religious Affairs made effort to add the hours of religious education in elementary and secondary level becoming 6 hours a week. This was part of continues effort of the ministry to expand religious education in schools, although the Department of Education and Teaching did not give permission. According to Mudyahardjo (2002: 459), in the early 1980s, couple years before the national curriculum of 1984 was released, there was a suggestion to include religious comparative curricula as part of the national curriculum in senior high school, but it was rejected by some Muslim groups, arguing that it could broke and weaken the faith of the students.

In line with this, Sirozi (2004) argued that there was a significant change in 1989 regarding to the release of Laws No. 2 Year 1989 about the National Education System. The fundamental distinction lied on the holder of religious education. Based on Laws of Education No. 4 Year 1950 and No. 12 Year 1954, it was only public schools that hold religious education and parents had authority to determine whether their kids would follow religious class or not. In the new law of national education system No. 2/1989, there was no explanation about public schools as the only type of school that holds religious education. As a consequence, all schools, either public or private, should hold religious education. But, schools which are based on certain religion have no obligation to hold religious education outside its own religion. This policy was strengthened by the release of PP No. 29/1990 explaining that school which is based on certain religion was not obliged to teach religion outside its own religion. Many Muslim leaders opposed this regulation, because they were worry about Muslim students who study at Christian schools. Based on this regulation, are not required to provide religious education outside its own religion. For Christian people the Education Law 1989 was very fair because it accommodated community's right. Holding an education based on certain religion was part of right of religious community. Thus, the right of student to receive religious education of his/her own religion can only be applied in state's school, not private's school, and Christian schools are part of private's schools.

In the period of reformation era (1998 onwards), the dynamic and development of religious education continued to take part, particularly with the release of UU No. 20/2003 about National Education System. This Education Law said that the function of national education is "to develop the nation's competence, character, and civilization that is based on dignity in order to enlighten national life, aimed at developing students' capacity in order to make them become human beings who are pious and having noble character, healthy, 
erudite, skillful, creative, independent, and becoming democratic and responsible citizenship."

In regard to religious education, the Law regulates, among others: (1) Religious education is held by the government and/or group of community from certain religious adherent, in accordance with the regulation of laws; (2) The function of religious education is to prepare students as part of community members who understand and apply religious values and/or become expert of religion; (3) Religious education could be held at formal, non-formal, and informal education; and (4) Religious education could be in the form of diniyah, pesantren, pasraman, pabhaja samanera, and the like.

There are many interesting sections in the Education Law No. 20 Year 2003 concerning religious education. Section 12, paragraph 1, part a, for example, says "Each student in every unit of education has right to (a) receive religious education in his/her own faith from a teacher of that faith." This Section is then regulated further on the Government Regulation No. 55 Year 2007 Section 3 Verse 1, saying that "Every unit of education at all lanes, levels, and types of education is obliged to hold religious education," and Section 4 Verse 2 stated, "Every student at all lanes, level, and types of education has right to receive religious education in his/her own faith from a teacher of that faith."

The statement of "every student has a right to receive religious education in his/her own faith from a teacher of that faith" is a controversial one. Before the Education Law No. 20 Year 2003 was issued and executed there were demonstrations that are for and against the law, and in particular, in regard to this section. For those who support the law, most of them were Muslims. They argued that the law was an ideal one, because it could protect individual's right to receive religious education from a teacher of that faith, regardless of what kind of school he/she takes. In fact, many Muslim parents sent their children to Christian schools, arguing that the latter could provide a good quality of education, but they were worried about two things: the child might be converted to Christianity or become a skeptical and uncommitted Muslim. In order to avoid Muslim students convert to Christianity or make them sceptical to their own religion, some prominent Muslim leaders suggest three things: first, they asked the Muslim communities not to study at Christian school; second, the Muslims should try to establish and develop a better quality of Islamic private schools to compete with the Christian schools; third, they demanded the government to provide a regulation that obliges every private school to provide a religion class according to the religion of the students (See, Mujiburrahman, "State Policies on Religious Diversity in Indonesia," Al-Jami'ah, Vol. 46 No. 1 Thn 2008). To avoid these things happen, they did not allow their children receive religious education outside the religion of their own. In one hand, this was a dilemma because they want Christian school. On the other, they did not want their children receive Christian religious education. The present of the Education Law No. 20 Year 2003 and PP No. 55 Year 2007 was part of the 
solution, because they would guarantee Muslim students who enroll at Christian schools to receive religious education in their own faith from a teacher of that faith. The same thing would happen to those Christian students who enroll at Islamic schools, like Muhammadiyah schools in NT'T; they would receive Christian religious education. On the other hand, people who were against the law, most of them non-Muslims, argued that holding a school based on certain religion is a right of certain community. Anybody who preferred to study to this kind of school should follow the rules and regulations decided by that school; otherwise community's right was not respected. What kind of religious education would be taught at that school is fully in the hand of the school, and all students of that school should follow. Another argument why most of Christian schools reject the law was because there would be very difficult for them to provide religious teachers for Muslim students, and even some of them were doubt that there would be available good Muslim teachers who have inclusive perspective on Islam. Some of Christian schools guaranteed that there would not happen a conversion of Muslim students to religion of that school, as many Muslims were worry about.

From the above historical overview on religious education, some interesting conclusions can be drawn:

First, religious education had been introduced to formal education since the early independence of Indonesia and even it was located as part of national education system. The issue of Education Law No. 2/1989 and then revised by No. 20/2003, wherein religious education was part of them, was an indication that the state paid a serious attention to religious education, although Indonesia is neither secular nor Islamic state.

Secondly, there was always dynamic and fluctuation in applying religious education in practice. In the early conception of religious education, it was merely taught at $4^{\text {th }}$ class to $6^{\text {th }}$ class. But as an exception was made for certain regions that have very strong religious tradition, and in such regions religious education had been introduced since $1^{\text {th }}$ class. Since the New Order era, religious education was a compulsory lesson from elementary school until university as stated at the Education Law No. 2/1989, and even in the Education Law No. 20/2003, Section 12, paragraph 1, part a, stating that "Each student in every unit of education has right to receive religious education in his/her own faith from a teacher of that faith." This section has led to serious debate and controversy in mass media for a quite long between those who support and against.

Third, the government established three committees for managing religious education only in five years (1947-1952), beginning from the Consideration Council of Islamic Teaching in 1947 led by Ki Hajar Dewantoro and Prof. Drs. Abdullah Sigit, then in 1950 the government established a new committee led by Prof. Mahmud Yunus from the Department of Religious Affairs and Mr. Hadi from the Department of Education and Culture, and in 1952 the government established the other committee led by KH. Imam 
Zarkasyi. Thus, only in five years (1947-1952) the government had established three committees in order to rearrange religious education in Indonesia, and this showed that the government paid a serious attention to this issue.

Fourth, in the early 1980s, couple years before the national curriculum of 1984 was released, there was a suggestion to include religious comparative curricula as part of the national curriculum in senior high school, but it was rejected by some Muslim groups, arguing that it could broke and weaken the faith of the students. This means that in the past, there was ever an idea to formulate curricula of religious education that contains comparative of religion in order to make students of different faith know and respect each other.

\section{The Challenge of Religious Pluralism}

Nobody would deny that Indonesia is a pluralist society, proven by the fact that there are many religions, many religious organizations, and many interpretations of religion, either in the past, today, or in the future. Long ago, an Indonesian Islamic observer, Geertz (2011: 11) reminds us that Indonesia "is not just locally, accidentally and temporarily pluralist. It is, to commit a philosophical solecism and a political truth, pervasively, essentially, and permanently so." Pluralist society is a common phenomenon in the world, not only in Indonesia; it is hardly to find a homogenous society within one country due to the massive impact of globalization and urbanization.

Plurality of religions is ambiguous in nature, because it could enrich religious experiences as well as bear disharmony and violence within religious adherents. When plurality of religions is interpreted in very narrow minded it would be danger and at least three things would happen. First, there would emerge truth claim, in the sense that truth is not owned anymore by all religions, but is limited to only certain religion. Certain religion is perceived as the only true truth. The second negative impact of narrow minded interpretation of religion is a monopoly of religious exegesis, and this is part of a result of monopoly of truth claim. At this point, certain group claims that true interpretation of religion is only theirs, others are wrong or unjustified. This monopoly of religious exegesis contributes to make interpretation of religious texts as sacred as the Holy Book itself. The next impact is the emergence of violence in the name of religion; religion is used to justify violent action. Doctrine of "jihad", for example, is often used to justify violence action (Rahman, 2010: 492-494).

According to The Wahid Institute, violence in the name of religion is common phenomenon in Indonesia. Based on the Annual Report of Religious Life, published by CRCS, UGM, there were 54 cases of religious-based violence in Indonesia during the year 2009; 18 cases in relation to the establishment of place for worship; 25 cases in relation to misguided religion; and 11 cases in relation to Ahmadiyah group of Islam (The Wahid Institute, http://wahidininstitute.org/2012/05/01). 
Moroever, The Wahid Institute gives more detail on the issue of violence in the name of religion. According to this organization, there were 63 cases on the violation of religious freedom; victim of people: 15 people $(20 \%)$; victim of place of worship and its adherents: 34 (45\%), and victim of those who suspected deviate: 26 community (34\%). Moreover, the Wahid Institute reports that there were 133 cases in term of intolerant actions during 2010, taken place in West Java, East Java, Jakarta, DIY/Central Java, North Sumatra, Aceh, NTB, Sulawesi, Kalimantan, South Sulawesi, Jambi, North Lampung, and Riau. This fact shows that intolerant actions in the name of religion still need a serious attention for those who have concern with religious life in Indonesia.

The case would be very different when religion is interpreted in openminded and contextual setting. From this perspective, religious pluralism is very understandable and its existence should be respected. Religious pluralism is a worldview that believes source of truth is not exclusively owned by certain religion, but all religions owned it. No religion teaches its people to do bad deed, but good deed. In fact, there are a lot of universal good values of religions that possibly can be employed as meeting points of religions. Saying this fact does not necessarily mean that all religions are the same; of course, they are different in many aspects. In another language, there are similarities and dissimilarities among religions. Religious pluralism refuses the notion that truth is only owned by or monopoly of certain religion, because this notion is against the principle of equity of religion. Monopoly of truth claim is against the principles of pluralism, because it assumes that one is more superior than the other. Superiority claim of certain religion contributes to locate other religions as inferior, and this lead to path the way of unequal relationship among religious adherents.

Madjid, as quoted by Munawar-Rachman (2001), explains three attitudes towards dialogue of religion, namely exclusive, inclusive, and pluralist. Exclusive attitude is an attitude that seeing his/her own religion as the only true religion, while others are wrong. Inclusive attitude is an attitude that seeing other religions as an implicit form of our religion. In another language, there are meeting points of religions. Pluralist attitude is an attitude that sees other religions as the same path to achieve the same truth. According to Madjid cited in Munawar-Rachman (2001: 31), the truly Islam has inclusive and pluralist character. Another scholar, Shihab (1997: 41-42) gives some notes on religious pluralism. First, religious pluralism does not only acknowledge plurality of religions, but also actively involves in that plurality. In other language, individual is not only demanded to acknowledge the existence and rights of people with different faith, but also participate in understanding the similarities and differences of religions. Secondly, religious pluralism should be distinguished from the idea of cosmopolitanism, where many religions live in one area but they never communicate and interact one over the other. The philosophical basis of cosmopolitanism is individualism. Third, religious pluralism does not mean relativism, a notion that locates everything, including religion, as a relative truth. 
Thus, a person is a pluralist when he/she does not only acknowledge the existence and the rights of other religions, but also involve in understanding the similarities and differences to achieve harmony within plurality. Acknowledging the existence and rights of other religions is only enough to reduce fanaticism, but it is not enough to contribute to strengthen the existence of pluralism. Using Nurcholis Madjid's term, it is only "negative goodness." According to him, as quoted by Munawar-Rachman (2001), pluralism should be understood as "genuine engagement of diversities within the bond of civility." Meanwhile, Ghazali (2009: 394) defends clearly and strongly religious pluralism within Islam by presenting theological and historical arguments. He quotes one of mufassir that said al-din wahid wa al-syariat mukhtalifat (religion is one, and the manifestation of religion is diverse).

There are two mainstreams in the discourse of religious pluralism: perennial philosophy approach, based on the thought of Guénon (1886 - 1951) and Schuon (1907 - 1998), and global theology approach, initiated by Hick (1922- ). Guenon does believe that every religion has different way and method to achieve "the Oneness of Truth" and this difference is part of different manifestations in understanding the Ultimate Reality. Guenon concludes that all religions do have truth and are united at the esoteric level, although at the exoteric level they are different one another. Another perennial philosophy scholar, Schuon (1993), comes with the idea of the transcendent unity of religions. Like Guenon, Schuon (1993) divides religion into two entities: exoteric and esoteric. Looking at exoteric dimension, all religions have different expressions and manifestations; they are different in terms of rituals, place for rituals, and the like. They have their own way to be closed to the Ultimate Truth. However, at the esoteric dimension all religions have common goal to go to the Ultimate Truth.

The second school of religious pluralism is the one proposed by John Hick as global theology. He employs globalization as a means to construct his concept on religious pluralism. Globalization is a process of unification of life dimensions globally. This trend of globalization gives impact to the unification of religious expression globally, or what he calls as "global theology." Hick predicts that someday religions would be more as sects than as exclusive and radical entities. This would happen with condition that there will be a process of transformation of orientation from self-centeredness (centered at each religion) to God-centeredness. According to Hick, religions are diverse and different from one to another because they have long experience in responding the Absolute Reality. The Absolute Reality is actually one and undivided, and only then it was interpreted differently by human beings based on their sociohistorical context. As a result, there many images of what is called by God, or to use Hick's language, "relative gods." The Real and Absolute God actually is only one, and undivided. 


\section{Changing Model of Religious Education}

Facing the challenge of religious pluralism, it is necessary to rethink the concept and praxis of religious education in Indonesia. There are two reasons available. First, the mission and function of religious education actually is to make religion meaningful for human life and not to make disharmony and tension among people of different faiths. However, the present of religious education in Indonesia, particularly with the present of Education Law No. 20/2003, has created tension among people of different faith. Political interest is very obvious in this case, where each group always makes effort to win the competition with its own argument. Basically, the root of the problem is about competition between "individual" and "community" rights; whether religious education is part of individual or community's rights. Secondly, the orientation of religious education is only to learn about its own religion, without connecting it with other religions. To use conceptual framework as mentioned earlier, this kind of orientation is part of model of religious education in the wall, and this model is inadequate to face the challenge of religious pluralism.

Therefore, in order to face the challenge of religious pluralism, it is ssuggested to change the model of religious education from in, to at and beyond the wall, as proposed by Seymour (1997) and Christiani (2009). These models of religious education basically are parallel with that of composed by Nurcholish Madjid as exclusive, inclusive, and pluralist models. It is undoubtedly that model of religious education in the wall is inadequate to face the challenge of religious pluralism, and this is the reason why it is necessary to change the model to at and beyond the wall.

Why religious education in the wall cannot face the challenge of religious pluralism in Indonesia? As it was explained earlier, religious education in the wall means speaking the language used within the faith community; it is a phase of faith formation in studying only one's own tradition, without connecting it with other tradition. Borrowing Nurcholis Madjid's term, this is typical of exclusive model of religious education that has two characters: (a) monopoly of religious truth, as if only certain religion who has truth, others are wrong; and (b) monopoly of religious exegesis. Monopoly of religious truth is basically driven by "high profile of religiosity," which leads individual to have psychology of superiority. This type of psychology undoubtedly drives people to locate the others in unequal position.

In addition, the model of religious education in the wall contributes to grow prejudice and misunderstanding of people of different faith, because there is no enough knowledge of other religions. The source of prejudice is because of lack of information of those who we perceive as "the others". Prejudice and misunderstanding can be reduced if there is enough room and space for people of different faith to interact and know each other, and model of religious education in the wall fails to provide this kind of room and space. Not only this model contributes to grow prejudice and misunderstanding, but it is also 
responsible for reducing tolerant attitude, sympathetic, and emphatic of people with different faith. Without knowing other traditions could also produce distorted images of others and their faiths and raise sense of superiority of one over the other. In the near future, this model of religious education does not help people of different faith to be closed to each other, but in contrast, it remotes one another and affirms the demarcation line between "I" and "You"; "We" and "They".

Since religious education in the wall is inadequate to face the challenge of religious pluralism, it is necessary, therefore, to change the model to at and beyond the wall. As it has been discussed previously, religious education at the wall means using common terms to speak to the world or other faiths. This is a phase of faith transformation by learning and appreciating people of other faiths and conducting interreligious dialogue. Interreligious dialogue can be seen as a search for the maximum common denominator, or as a broader sense of "common values." This model of religious education helps people to "see themselves as the others," and thus, reduce the sense of superiority of one over the other. The willingness to know the others would widen perspective and knowledge, avoid misunderstanding and prejudice, and develop a sense of respect and appreciation to other religions. This can be employed as religious modality to follow what Kimball (2003) calls as "passing over and coming back," that is, temporarily leaving one's own tradition to enter another tradition and then returning back to his/her own tradition. This concept helps students to enrich their own faith, appreciate the existence of other faiths, and recognize the particular and universal values of religions. Religious education at the wall gives new perspective and insight to students of different faith to know, respect, and value differences. The key word to face the challenge of religious pluralism is by acknowledging and respecting the existence of each other.

Knowledge about other religions is an important precondition for the development of a culture of tolerance, and it helps to discover the shared values of religions. The exclusivity of certain religious or philosophical views and beliefs does not mean a negation of the principle of tolerance. Tolerance presupposes that you have a basic conviction that differs from the convictions of the person that you tolerate. However, there are meeting points of religions that can be shared, and these meeting points or values cannot come into existence without willingness to know each other. In sum, religious education at the wall contributes to shape individual of different faiths to accept, respect, and value differences. Thus, religious education at the wall contributes to enlighten religiosity of people of different faiths by seeing themselves as the others. With such position, there will be no claim of superiority of one over the other.

Looking from the perspective of taxonomy bloom theory, model of religious education at the wall is still in the domain of cognitive and attitude, and therefore, it's contribution is limited to acquire the knowledge, attitudes, and skills needed to function effectively in a pluralistic society. To face the challenge 
of religious pluralism, cognitive and attitude domain is inadequate. It is necessary, therefore, to combine this model with that of religious education beyond the wall as proposed by Cristiani (2009). In other words, religious education beyond the wall is a phase of faith praxis. It helps students to work together with people of other faiths for peace, justice, and harmony. This model of religious education develops and strengthens solidarity of students of different faiths. Different faith is not a barrier to work together in the sake of humanity, because the prophetic mission of all religions is to make a better life for people in the earth. Religious education beyond the wall helps students to connect between theory and practice, knowledge and deed. Thus, this model helps students to have ability to interact, negotiate, and communicate with peoples from different faiths. In the long run, this type of religious education contributes to create a civic and moral community that works for the common.

Moreover, giving opportunity for students of different faiths to work together would show them that the real enemy of religions is not among people of different faiths, but poverty, ignorance, violence, corruption, illegal logging, and the like. The prophetic mission of all religions is combating these problems, while at the same time, promoting justice, harmony, and peace. Religious education then is not only a matter of how to transfer religious teachings, but more than that it is a process of transferring, internalizing, and practicing religious knowledge into daily life. Teaching religion does not only in the realm of theory or concept, but praxis as well. Religious education should not only seek to propagate itself, but also to serve humanity.

Why praxis is necessary as a part of learning religion? The goal of religious education is not only to make students having knowledge about religion, but more than that, how students can internalize such knowledge into their mind and body and, in turn, give positive impact to their daily action. In order to make religious education has praxis orientation, it is better to turn to the work of Taylor (1993). He suggests involving three stages in teaching religion. The first stage is what he calls as naming, that is, a stage of questioning the problem: what is the problem? This is a process of helping students to ask something, or to use Paulo Freire's term, "learning to question." To sharpen the question, it should be continued by the second stage: reflecting, that is, raising question to seek the root of the problem: why is it happening? In order to make these stages do not trapped at rhetoric level, it is necessary to continue to the last stage: acting, that is, process of seeking alternative solution to the problem by proposing question: what can be done to change the situation? The last question is part of praxis question, because it encourages students to solve the problem by taking action.

\section{CONCLUSION}

Religious education is always ambiguous and not neutral; it is always based on certain interest, ideology, and philosophy (Giroux: 1997). Moreover, Religious education is possible to bear individuals who are tolerant or intolerant; 
respect or disrespect a plurality of religions; value or disvalue differences; and strengthen or weaken the spirit of pluralism-multiculturalism (Nuryatno: 2008). Indonesia is a pluralistic society, and religion plays an important role in this country. This can be seen from the fact that religious education had been applied to formal school soon after the independence of Indonesia. The present of Education Law No. 20/2003 shows how religious education cannot be separated from the national system of education, although the present of this Law produced controversy in society, particularly dealt with the dictum "every student has a right to receive religious education in his/her own faith from a teacher of that faith." As part of education policy, this kind of controversy is common, because there is no policy that can satisfy all groups in society. Any public policy always gives advantage to certain group and gives disadvantage to other group. Looking from theory of models of religious education, the application of religious education in Indonesia adopts the model of religious education in the wall, that is, speaking the language used within the faith community; it is a phase of faith formation in studying only one's own tradition, without connecting it with other tradition. This model is adequate to face the challenge of religious pluralism in Indonesia, because it tends to shape individuals who have an exclusive type of religiosity. For this reason, it is necessary to change the model into at and beyond the wall, arguing that these models would likely to shape individuals who have ability to accept, respect, and value differences, on one hand, and have ability to interact, negotiate, and communicate with people of different faith, on the other. These models would give individuals social modality to live in very pluralistic society like Indonesia. In the past, there was the same spirit to accommodate the model of religious education at and beyond the wall through "religious comparative curricula" as part of the national curriculum in senior high school, although it was rejected by Muslim groups. Today, some schools apply models of religious education that have the same spirit with models of at and beyond the wall, like for example, "religiosity education," under Catholic school; "faith communication education" at SMA BOPKRI Yogyakarta Indonesia and "inclusive religious education" at SMA Piri Yogyakarta (Listia, 2007: 149-197).

\section{REFERENCES}

Annual Report of Religious Life. 2010. CRCS (Centre for Religious and CrossCultural Studies), UGM.

Christiani, Tabita K. 2009. "Christian Education for Peacebuilding in the Pluralistic Indonesian Context." In Religion, Civil Society and Conflict in Indonesia, Zurich: LIT VERLAG GmbH \& Co. KG Wien, pp. 173-191.

Geertz, Clifford. 2001. "The Near East in the Far East: On Islam in Indonesia." Occasional Paper of the School of Social Science, p. 11. 
Ghazali, Abd. Moqsith. 2009. Argumen Pluralisme Agama: Membangun Toleransi Berbasis Al-Qur'an. Depok: KataKita.

Giroux, Henry A. 1997. Pedagogy and the Politics of Hope: Theory, Culture, and Schooling. Boulder, Colo.: Westview Press.

Grimmit, Michael Grimmit. 1987. Religious education and buman development. Great Britain: Mc Crimmon.

Habermas, Jurgen. 1971. Knowledge and Human Interest. Boston: Beacon.

Kimball, Charles. 2003. Kala Agama Jadi Bencana. Bandung: Mizan.

Listia, Laode Arham, and Lian Gogali. 2007. Problematikan Pendidikan Agamadi Sekolah. Yogyakarta: Interfide.

Laporan Kebebasan Beragama/Berkeyakinan Tahun 2010, The Wahid Institute, http://wahidinstitute.org/files/_docs/RINGKASAN\%20EKSEKUTIF \%20KEBEBASAN\%20BERAGAMA\%202010.pdf. Diakses pada tanggal 01 Mei 2012.

Mujiburrahman, "State Policies on Relgious Diversity in Indonesia," Al-Jami'ah, Vol. 46, No. 1 Thn 2008.

Mudyahardjo, Redja. 2002. Pengantar Pendidikan: Sebuah Studi Awal tentang Dasardasar Pendidikan pada Umumnya dan Pendidikan di Indonesia. Jakarta: Rajawali Press, 2002.

Munawar-Rahman, Budhy. 2010. Reorientasi Pembaruan Islam: Sekularisme, Liberalisme, dan Pluralisme Paradigma Baru Islam Indonesia. Jakarta: LSAF dan Paramadina.

Munawar-Rachman, Budhy. 2001. Islam Pluralis. Jakarta: Paramadina.

Nuryatno, M. Agus. 2010. "Pendidikan Islam Dalam Sistem Pendidikan Nasional," dalam Pendidikan Islam di Dunia Melayu: Perbandingan Malaysia dan Indonesia. Japan: Asian Cultures Research Institute, pp. 287-304.

Nuryatno, M. Agus. 2008. Mą̧bab Pendidikan Kritis. Yogyakarta: Resist Book, 2008.

Schuon, Frithjof. 1993. The Transcendent Unity of Religions. Wheaton, Ill.: The Theosophical Publishing House.

Shihab, Alwi Shihab. 1997. Islam Inklusif: Menuju Sikap Terbuka dalam Beragama Bandung: Mizan, pp. 41-42.

Sirozi, Muhammad. 2004. Politik Kebijakan Pendidikan di Indonesia: Peran TokohTokoh Islam dalam Penyusunan UU No. 2/1989. Leiden-Jakarta: INIS.

Stenbriink, Karel. 1994. Pesantren, Madrasab, Sekolab: Pendidikan Islam Dalam Kurun Moderen. Jakarta: LP3ES.

Symour, J.L. (ed). 1997. Mapping Christian Education: Approaches to Congregational Learning. Nashville: Abingdon Press.

Taylor, Paul V. 1993. The texts of Paulo Freire. Philadelphia: Open University Press.

Zuhairi, dkk. 1997. Sejarah Pendidikan Islam. Jakarta: Bumi Aksara. 